\title{
Urgences
}

\section{Après Antée}

\section{Gilles Cyr}

Numéro 15, octobre 1986

Épigraphiques

URI : https://id.erudit.org/iderudit/025308ar

DOI : https://doi.org/10.7202/025308ar

Aller au sommaire du numéro

Éditeur(s)

Urgences

ISSN

0226-9554 (imprimé)

1927-3924 (numérique)

Découvrir la revue

Citer ce document

Cyr, G. (1986). Après Antée. Urgences, (15), 41-42.

https://doi.org/10.7202/025308ar

Ce document est protégé par la loi sur le droit d'auteur. L'utilisation des services d'Érudit (y compris la reproduction) est assujettie à sa politique d'utilisation que vous pouvez consulter en ligne.

https://apropos.erudit.org/fr/usagers/politique-dutilisation/ 


\section{Gilles Cyr APRÉS ANTÉE}

C'est une chose étrange, ou même une chose sinistre, que de devoir d'abord sauter pour atteindre le sol même sur lequel nous nous trouvons.

Martin Heidegger: Qu'appelle-t-on penser?

1

Ils s'aperçoivent tournoyant dans l'air, qui est un mélange

2

je dois d'abord sauter, ou sauter d'abord?

3

dans la clairière contiguë

les candidats lessivés

4

j'ai essayé une fois

il y a des années

la réception je crois avait suivi une suspension

5

des provisions ne vont pas au terrier où la bête n'est pas rentrée

6

pendant que je me lève encore:

"vous recevrez bientôt une émission cohérente" 
là-bas le plancton aérien riche en petits arthropodes. 